ment are similar or identical to those necessary for development of the filarial larvae.

The life cycles of many parasites involve insects as intermediate hosts. An in vitro method for investigating this phase of development of a parasite, offering conditions closely approximating the environment in the insect, is highly desirable. Insect cells in culture may provide this method.

DUell E. WOOD

EARL C. SUITOR, JUN.

U.S. Naval Mcdical Research Unit No. 2,

Taipei, Taiwan.

${ }^{1}$ Earl, P. R., Ann. N. Y. Acad. Sci., 77, 163 (1959).

2 Sawyer, T. K., and Weinstein, P. P., J. Parasitol., 49, 218 (1963).

${ }^{3}$ Weinstein, P. P., Trans. Roy. Soc. T'rop. Med. Hyg., 57, 236 (1963).

"Grace, T. D. C., Nature, 211, 367 (1966).

- Suitor, jun., E. C. (unpublished work).

- Grace, T. D. C., J. Gen. Physiol., 41, 1027 (1958).

; Grace, T. D. C., Nature, 195, 788 (1962).

\section{Types of Group Selection}

THe tcrms group seloction and intergroup selection ${ }^{1,2}$ have been used in referring to a varioty of phenomena including recently the evolution of behavioural social systems involved in population control ${ }^{3,4}$. Since the phenomenon of group selection promises to recoivo greater attention from students of evolution in the future, I fcel that a clarification of terms at this time will help to prevent confusion. The "groups" under consideration may be quite different from each other and the action of natural selection on them will depend on the nature of the group.

At least two extreme types of group can be recognized: the family or lineage group and the population. Intermediate types occur, especially in species in which culture is important, but only the extreme types will bo discussed here. The lineage group is a sub-group within a population, and is defined on tho basis of kinship. A population in the ecological sense, although it may also havo a common lineage, is generally defined from other populations spatially, irrespective of lineage. Theoretically the two concepts can overlap, but in practice this is not embarrassing. The term kin selection may be applied to lineage groups (following Smith $^{5}$ in part). The evolution of parental care, whether bchavioural, morphological or physiological, may be attributed to kin selection.

Tho simplest lineage group is composed of one or more parents and their offspring. In the typical caso the family group disperses before the first generation has reached maturity. In somo social insects, a few species of birds, and in some other animals, the young remain with the paronts and help to raise subsequent broods, as in some cases of "helpers at the nost" 6 . Among birds, in the Mexican jay (Aphelocoma ultramarina) ${ }^{7}$, fairy wren (Malurus cyaneus) $)^{8}$, Australian magpies (Gymnorhina dorsalis ${ }^{8}$ and $G^{\gamma}$. tibicen $)^{10}$, and some other species ${ }^{11}$, territories may be defended by social groups larger than pairs, in which incipient communal behaviour may occur; but the most extreme development of this evolutionary potentiality in birds appears to be the situation found in certain anis (Crotophaginae) in which all phases of breeding may be communal11. In the latter cases, the oxtent to which inbreeding determines the genetic composition of successful groups is not known but deserves study.

Assuming lineage to bo important in the latter cases, we can then recognize a continuum among various species in the importance and complexity of the family or lineage group and in the numbor of gonorations in which it may stay together as a unit. The existence of such a continuum is provided for in the expression "inclusive fitness" in Hamilton's ${ }^{12}$ model for kin selection. It is possible at all positions on this continuum to recognizo the existence of competition between lineage groups. This may be done whether the unit is a pair of titmice and their brood and the competition influences the evolution of
Table 1. Characteristics of Two Types of Group Selection

\begin{tabular}{|c|c|c|c|c|}
\hline & \multicolumn{2}{|c|}{ Kin selection } & \multicolumn{2}{|c|}{ Interpopulation selection } \\
\hline & $\begin{array}{l}\text { Simple } \\
\text { extreme }\end{array}$ & $\begin{array}{c}\text { Complex } \\
\text { extreme }\end{array}$ & $\begin{array}{l}\text { Slight } \\
\text { ecogeographic } \\
\text { separation }\end{array}$ & $\begin{array}{l}\text { Large } \\
\text { ecogeographic } \\
\text { separation }\end{array}$ \\
\hline $\begin{array}{l}\text { Lineage } \\
\text { relationship }\end{array}$ & $\begin{array}{l}\text { Simple } \\
\text { family }\end{array}$ & Communal & Irrelevant & Irrelevant \\
\hline $\begin{array}{l}\text { Duration of } \\
\text { group }\end{array}$ & One & Indefinite & Indefinite & Indefinite \\
\hline $\begin{array}{l}\text { Gene ex- } \\
\text { change } \\
\text { between } \\
\text { groups }\end{array}$ & Unrestricted & $\begin{array}{l}\text { Partially } \\
\text { restricted } \\
\text { by social } \\
\text { hehoviant }\end{array}$ & $\begin{array}{l}\text { Partially } \\
\text { restricted } \\
\text { by geography }\end{array}$ & Nearly absent \\
\hline $\begin{array}{l}\text { gompersition } \\
\text { between } \\
\text { groups }\end{array}$ & Sympatric & $\begin{array}{l}\text { behaviour } \\
\text { Sympatric }\end{array}$ & Allopatric & Allopatric \\
\hline
\end{tabular}

clutch size ${ }^{13}$ (simple extreme in Table 1) or if the unit is a flock of anis (Crotophaga spp.) and the competition determines the social organization and behaviour of the flock and species (complex extreme in Table 1). The critical point in all these cases is that the group is characterized (to varying degrees) by a common lineage, which is characteristically maintained by social bonds within a population and with no important ecogeographic isolation from other such groups. The ovolution of the ability to form such social bonds is also provided for in Hamilton's ${ }^{12}$ model.

Smith $^{5}$ has referred to one extreme of this continuum as "group selection" and to the other extreme as "kin selection". In my opinion, because these cases may be recognized as lying along a continuum (provided for in Hamilton's ${ }^{12}$ model) thoy should all be interpreted as representing one phenomenon, which may conveniontly be called kin selection, or perhaps lineage selection. To use the term "group selection" for any of these cases is confusing, as Wynne-Edwards" ${ }^{3,4}$ has used "group selection" and "intergroup selection" in explicit reference to intraspecific interpopulation competition, which is quite a different phenomenon. In order to avoid confusion I propose the following definitions: selection between lineage groups within populations will be called kin selection; selection between spatially defined (allopatric) populations of a species will be called interpopulation selection (seo Table 1).

Whether the term group selection will eventually prove useful as a generic term to include both kin selection and interpopulation selection remains to be seen. The differences between the two are significant. Kin scloction depends on sympatric competition between lineage groups within a population and can be treated theoretically in a manner comparable to individual selection ${ }^{12}$, since the basic time unit is most frequently the generation and the lineage groups are not prevented from interbrecding except partially in the complex cases, as in species with communal territories. Interpopulation selection depends primarily on allopatric competition; the basic time units are the time constants for extinction and colonization, and it may require a differont type of mathematical expression, such as game theory ${ }^{14}$.

This investigation was supported in part by a research grant from the National Institute of Mental Health, U.S. Public Health Sorvice.

JERraM L. Brown

Department of Biology and Conter for Brain Research, University of Rochester,

Rochester, New York.

${ }^{2}$ Wright, S., Ecology, 26, 415 (1945).

${ }^{2}$ Wright, S., Amer. Nat., 90, 5 (1956).

3 Wynne-Fidwards, V. C,. Animal Dispersion in Relation to Social Behaviour (Oliver and Boyd, Edinburgh and London, 1962).

${ }^{4}$ W ynne-Edwards, V. C., Nature, 200, 623 (1963).

Smith, J. M., Nature, 201, 1145 (1964).

- Skutch, A. F., Condor, 63, 198 (1961).

" Brown, J. Y., Condor, 65, 126 (1963).

$\checkmark$ Rowley, I., Emu, 64, 261 (1865).

- Rowley, I., Emu, 64, 261 (1965).

10 Rabinson, A., Emu, 56, 233 (1956).

${ }^{11}$ Davis, D. E., Quart. Rev, Biol., 17, 115 (1942).

12 Hamilton, W. D., J. Theoret. Biol., 7, 1 (1964).

${ }^{18}$ Lack, D., The Natural Regulation of Animal Numbers (Clarendon Press, Oxford, 1954).

14 Lewontin, J. Theoret. Biol., 1, 382 (1981). 